\title{
The Weeds of Arable Land. III.
}

\author{
BY
}

\author{
WINIFRED E. BRENCHLEY, D.Sc., F.L.S. \\ Rothamsted Experimental Station (Lawes Agricultural Trust).
} NITIAL investigations carried on in parts of Bedfordshire and the West
Country ${ }^{1}$ have shown that while definite relations exist between the weeds and soils of arable lands, these relations are partly local and partly general in extent. It is evident that in some cases a weed that is symptomatic of a certain soil in one district is not so exclusively associated with it in another, but there are also indications that certain species are symptomatic or characteristic of the same type of soil in different districts. Naturally, the 'general' relations will need more exhaustive proof than the 'local', and a true estimate will only emerge gradually as the field of investigation is enlarged, since each fresh observation ratifies or discounts the previous deductions.

In the earlier work special care was taken to select districts in which drift deposits were conspicuous by their absence, so that the soils dealt with might be regarded in the main as derived from the geological formations immediately underlying them. In Bedfordshire, Wiltshire, and the Bath district large tracts of land exist overlying one particular formation, such as Greensand, Chalk, or Gault, so that one can feel some confidence as to the origin of the soil. It was found, however, that the geological derivation apparently has little to do with determining the weed flora, the texture being a far more potent factor. Chalk forms the great exception to this rule on account of its very peculiar nature. To verify this still further, in 1912 the scene of operations was transferred to Norfolk, where drift soils are dominant. Geologists aver that the soils in Norfolk are derived from glacial deposits, the supposition being that at two distinct glacial periods the country was invested by ice sheets, which on melting left the drift deposits known as 'North Sea Drift' and 'Boulder Clay'.2 These drift deposits are

1 Brenchley, W. E.: Weeds of Arable Land. I. Ann. Bot., xxv, No. xcvii, Jan. I9II, pp. I55-65. Ibid., II. Ann. Bot., xxvi, No. ci, Jan. 19I 2, pp. 95-109.

${ }^{2}$ See Harmer, F. W.: The Glacial Deposits of Norfolk and Suffolk. Trans. Norfolk and Norwich Naturalists' Soc., vol. ix, pp. 108-33.

[Annals of Botany, Vol. XXVII. No. CV. January, 1913.] 
very variable in nature and texture even within very circumscribed areas, gravel, sand, loam, and clay occurring in close proximity in many places. In some districts the Boulder Clay is very chalky in nature owing to the grinding up and mixing of the underlying chalk strata with the glacial deposits. In some parts of West Norfolk these underlying strata themselves crop out, so that it was possible to get some insight into the weed flora of the Chalk, Gault, and Lower Greensand in addition to that of the heterogeneous glacial soils.

In the course of the season's work the following places were taken as centres, and the weed flora was investigated for some miles round: North Walsham, Aylsham, Hargham, Bressingham, Harleston, Field Dalling, Swaffham, Marham, Snettisham, and Sandringham. The plan of campaign was the same as in the two previous years, and the relative prevalence of the weeds was again notified as-

(I) Dominant.

(2) Sub-dominant.

(3) Distributed.

(4) Occasional.

(.5) Scarce.

During the season's survey about 480 fields were visited, yielding a harvest of $\mathrm{I}_{2}$ species of weeds, belonging to $\mathrm{IO}_{4}$ genera. Of these 36 species, representative of 32 genera, were each seen once or twice only. The total number of species and genera occurring was far in advance of those from Bedfordshire and the West Country, though the number seen once or twice only was practically the same in each of the three districts.

The strictness with which the various plants keep to their several habitats of field and hedgerow is most remarkable. A very few species, such as Scabiosa arvensis and Centaurea nigra, are denizens of both habitats, but otherwise it is very rare to find any incursion from one to another, even at the extreme edges of the fields. As heretofore, only the plants growing in among the crops were considered as weeds.

The chief species of weeds, with their habitats and relative dominance, were as follows :

Ranunculaceae. Ranunculus arvensis. Confined to the heavier loams and clay. Seldom seen, never dominant.

Ranunculus repens. Distributed over all soils, but seldom seen on chalk. Once dominant on heavy loam, usually distributed.

Papaveraceae. Papaver Argemone. Only occasionally seen, on light loams. Never in any quantity.

Papaver Rhoeas. One of the commonest weeds. Chiefly on sand, very frequent on light loams and chalk. Often dominant. 
Fumariaceae. Fumaria officinalis. ${ }^{1} \quad$ Characteristic of light and chalky soils, never seen on clay. Occasionally dominant.

Cruciferae. Brassica alba. Very rarely seen, and then on light and sandy loam ; once dominant on sandy loam.

Brassica arvensis (B. Sinapis). Found on all types of soil. Specially frequent on clay and heavy loam, rare on sand. Sometimes dominant on chalk, clay, and loam.

Capsella Bursa-pastoris. Universally distributed on all soils; very common. Occasionally dominant on loam.

Raphanus Raphanistrum. Characteristic of chalk and sand. Occasionally dominant on chalk.

Sisymbrium Thalianum (Arabis Thaliana). Associated exclusively with light loams and sandy soils. Occasionally dominant, usually distributed.

Resedaceae Resedalutea. Confined to chalk and sand. Infrequent in occurrence, never dominant.

Violaceae. Viola tricolor. Characteristic of light soils, sand, and chalk. Never dominant.

Caryophyllaceae. Arenaria serpyllifolia. Confined to light sandy and calcareous soils. Occasionally dominant on light sandy loam. Far more frequently seen than in the previous years' work.

Cerastium vulgatum. Occurs on all types of soil, though rarely on clay. Generally distributed, never dominant.

Lychnis alba. Chiefly associated with the lighter soils and sandy loam, though it is found on all types of land. The plant is very widely spread, but only occurs in small quantities.

Lychnis Githago. Usually occurs on loam. Generally scarce in distribution.

Silene anglica. Confined to sandy soils. Never very prevalent.

Silene inflata (S. Cucubalus). Chiefly on chalky and light soils. Twice dominant on sand, but usually distributed or occasional.

Silene noctiflora. Practically confined to the light soils and chalk. Usually distributed, never dominant.

Spergula arvensis. Confined to sand and light soils of a non-calcareous character. Frequently dominant on sand.

Stellaria media. Distributed over all types of soil; occasionally dominant on the lighter lands.

Geraniaceae. Erodium cicutarium. Distributed on sand and very light soils.

1 The nomenclature throughout is now taken from Hayward's Botanist's Pocket Book, I 3 th edition, I909. In the earlier papers that of Bentham and Hooker's British Flora was used, and the old collective name ' Fumaria officinalis' is retained, as this genus is exceedingly difficult to subdivide in the field under the conditions of the investigation. Where any change has been necessary the name previously used is added in brackets. 
Geranium dissectum. Associated with heavy soils. Never dominant.

Geranium molle (including var. aequale). Confined to light and chalky soils. Once dominant on sand, but usually distributed.

Geranium pusillum. Only seen on light and chalky soils. Never dominant.

Rosaceae. Alchemilla arvensis. Characteristic of light and of sandy soils, very rare on chalk. Occasionally dominant, usually distributed.

Potentilla Anserina. Chiefly associated with medium soils, less frequent on sand and rare on clay. Occasionally dominant.

Potentilla reptans. Occurred on the heavier soils, especially clay, but never seen in any quantity.

Umbelliferae. Daucus Carota. Associated with all types of soil and occasionally dominant.

Scandix Pecten-veneris. Found on all soils except chalk, though seen occasionally on chalky loam. Once dominant on light loam.

Rubiaceae. Galium Aparine. Chiefly on heavy loam and clay. Never dominant, and only seen frequently at Bressingham and Harleston.

Galium sp. Distributed on all types of soils. (This was a species which defied identification. The plant grew flat against the ground, in a kind of mimic rosette, the leaves usually being in whorls of four. In many ways it resembled a squat form of $G$. Aparine, but it was never seen in flower or fruit. This form was only seen in West Norfolk, in the districts round Swaffham and Snettisham; G. Aparine occurred alongside it in some cases.)

Sherardia arvensis. Found on all types of soil, but more usually on the lighter loams and chalk. Usually occasional or scarce, but generally distributed on chalk.

Dipsaceae. Scabiosa arvensis. Chiefly on light and sandy soils, absent from clay. Distributed or scarce.

Compositae. Anthemis arvensis. Chiefly on sandy soils and chalk. Very rare on clay. Occasionally dominant.

Anthemis Cotula. Usually occurred on loam, but not often seen.

Artemisia vulgaris. Distributed on light calcareous soils.

Carduns mutans. Occurred on light and calcareous soils. Once dominant on sand.

Centaurea Scabiosa. Associated with light and chalky soils. Never seen on clay. Once dominant on sand.

Chrysanthemum segetum. Confined to non-calcareous sand. Not very frequent, but usually dominant when present.

Cichorium Intybus. Associated with chalky soils, though twice seen on sand. Usually scarce.

Cirsium arvense (Carduns arvensis). By far the most common of all weeds. Ubiquitous among all crops and on all soils. Frequently dominant. 
Filago germanica. Distributed on sandy and chalky soils.

Gnaphalium uliginosum. Characteristic of sandy soils. (The records for this plant obtained in 1910 and 1912 agree as to its habitat, and so do not fall into line with the usually accepted idea that it is a denizen of moist places.)

Matricaria Chamomilla. Occurred either on sand or heavy loam. Usually infrequent, but once dominant on sand.

Matricaria inodora. Distributed over all types of soil and occasionally dominant on light and sandy loams.

Senecio vulgaris. Found on all soils. Once dominant on sand.

Sonchus arvensis. Associated with all soils, but more especially with heavy loam and clay. Occasionally dominant.

Tussilago Farfara. Practically confined to clay and the heavier loams. Never dominant.

Campanulaceae. Legousia hybrida (Campanula hybrida). Occurred on the lighter soils, though infrequent on sand. Absent from clay. Never dominant, often scarce.

Primulaceae. Anagallis arvensis. Associated with all types of soil, but when it occurred on chalk it was scarce in distribution. Never dominant.

Boraginaceae. Echium vulgare. Characteristic of sand. Once dominant.

Lycopsis arvensis. Confined to light sandy land-apparently soils may be calcareous or not. Usually occasional or scarce.

Myosotis scorpioides (M. arvensis). Chiefly on sand and loam; rare on chalk. Never dominant.

Convolvulaceae. Convolvulus arvensis. Universally distributed as to soil, and frequently dominant. One of the commonest weeds, and often seen on root land before the seeds come up, in company with Cirsium arvense.

Scrophulariaceae. Bartsia Odontites. Chiefly associated with loam; never seen on chalk. Twice dominant on heavy loam.

Linaria Elatine. Characteristic of heavy soils. Scarce.

Linaria minor. Associated with sandy soils. Infrequent.

Linaria vulgaris. Characteristic of chalky soils. Usually distributed.

Veronica agrestis. ${ }^{1}$ Practically confined to light and sandy soils; from chalk. Rarely dominant.

Veronica arvensis. Chiefly on the lighter soils; scarce on chalk. Never dominant.

Veronica hederaefolia. Associated with sand and light sandy loams. Absent from clay and chalk. Once dominant on loam.

1 The exact distinction between $V$. agrestis and $V$. Tournefortii was not recognized at the beginning of the season's work, so possibly a few records of $V$. Tournefortii have been classed as $V$. agrestis, but not vice versa. However, it is evident that the error has not in any way affected the final results except as to the exact number of records of each of the two species. 
Veronica Tournefortii ${ }^{1}$ (V. Buxbaumii). Found on all types of soil, including chalk. Occasionally dominant.

Lamiaceae. Galeopsis Tetrahit. Characteristic of the lighter soils. Rare on chalk.

Mentha arvensis. Occurred on all types of soils, but especially on heavy loam. Twice dominant on loam.

Satureia Acinos. Chiefly associated with chalky soils. Never dominant.

Plantaginaceae. Plantago lanceolata. Distributed over all types of soil and occasionally dominant.

Plantago major (probably including var. intermedia). Universally distributed as to soil. Never dominant.

Illecebraceae. Scleranthus anmuus. Confined to sandy soils; never on chalk. Frequently dominant on sand.

Chenopodiaceae. Chenopodium album. Distributed over all soils and occasionally dominant.

Polygonaceae. Polygonum aviculare. Very common on all soils and often dominant.

Polygonum Convolvulus. As common as $P$. aviculare, but generally associated with loam and sand. Seen on chalky loam, but never on chalk. Frequently dominant.

Polygonum Persicaria. Practically confined to light sandy soils, though one instance of dominance was on clay. (This species often came in if any part of the field happened to be rather damp.)

Rumex Acetosella. Only found on sand and light loam; never associated with chalky soils. Sometimes dominant on sand.

Rumex crispus. Distributed over all soils and occasionally dominant. (Most Norfolk farmers say that this is the worst weed they have to deal with, but such constant war is waged against it that it is by no means conspicuous in the fields.)

Rumex obtusifolius. Only seen on sandy soils. Once dominant.

Euphorbiaceae. Euphorbia exigua. Chiefly found on clay and the heavier loams. Never dominant, often scarce.

Euphorbia Helioscopia. Usually on chalk and calcareous soils. Occasional or scarce in distribution.

Graminaceae. Agropyron repens (Triticum repens). Chiefly on heavy land, but also found on all soils except chalk. Frequently dominant.

Agrostis alba (including var. stolonifera). Associated with all soils. Frequently dominant.

Alopecurus myosuroides ( $A$. agrestis). Characteristic of heavy loams and clay; never seen elsewhere. Once dominant on clay.

Poa annua. Chiefly on loam and sandy loam; rare on chalk. Once 
dominant. (This species is said to be particularly common among fruit trees in plantations.)

Poa trivialis. Found on loam and clay. Never dominant.

Equisetaceae. Equisetum arvense. Associated with most types of soil, but less common on sand and absent from chalk. Occasionally dominant.

The classification of the weeds with regard to the soils they colonize is more difficult when dealing with the drift soils than when the directly derived soils are concerned. Well-marked soils as clay, chalk, and sand are relatively scarce, while loams of all categories are in the ascendant. Generally speaking, the soils are more intermediate in type than in any of the districts investigated previously. Still, an analysis of the lists shows that the weeds do fall into well-defined classes, loam taking its place for the first time as a special subdivision.

\section{A. Clay and Heavy Loam.}

Fields in this section were comparatively seldom seen, only about II per cent. of the total number being really heavy in nature. The heavy soils were chiefly located round Harleston and Bressingham, where they are derived from the Boulder Clay (so being of drift origin), and again in the neighbourhood of Snettisham and Marham. At Snettisham the heavy clay land is down near the sea and is apparently also derived from Boulder Clay, but at Marham an outcrop of the Gault occurs, exceedingly heavy clay being met with cheek by jowl with the sharply defined Chalk outcrop. The dividing line between the two formations is remarkably distinct in this district.

As is so usually the case, while plenty of varieties of weeds occur on clay soils as well as in other habitats, only a few species have a decided preference for the heavy lands, and practically none can be designated as absolutely symptomatic of clay, though a few are certainly characteristic.

The following were found in association with these soils :

Alopecurus myosuroides

Geranium dissectum

Heracleum Sphondylium

Linaria Elatine

Potentilla reptans

Ranunculus arvensis

Stachys palustris

Equisetum arvense

Euphorbia exigua

Galium Aparine

Tussilago Farfara

characteristic.

Matricaria Chamomilla-only seen on heavy loam and sand.

Never on clay. 


\section{B. Loams.}

By far the greater part of the soils investigated in Norfolk are loams, locally known as ' mixed soils', varying in texture from light sandy land to that oi a very heavy nature. A local distinction is drawn between a 'sand' and a 'light mixed soil' and between a 'heavy mixed soil ' and a 'clay', but this distinction does not hold good when the weed flora is considered. Between the lightest and the heaviest loams there is an intermediate range of loams with which certain weeds are more particularly associated. It seems as though some species of plants do not care for extremes of any kind, but flourish best in the less distinctive habitats. Among such species are :

\begin{tabular}{|c|c|}
\hline $\begin{array}{l}\text { Anthemis Cotula } \\
\text { Bellis perennis } \\
\text { Brassica alba } \\
\text { Chrysanthemum leucanthemum } \\
\text { Euphorbia Peplus } \\
\text { Lolium perenne } \\
\text { Lychnis dioica } \\
\text { Papaver Argemone }\end{array}$ & generally associated with loams. \\
\hline $\begin{array}{l}\text { Achillea Millefolium } \\
\text { Galeopsis Tetrahit } \\
\text { Legousia hybrida } \\
\text { Scabiosa arvensis } \\
\text { Sisymbrium officinale } \\
\text { Veronica agrestis }\end{array}$ & also on sand and sandy loam. \\
\hline
\end{tabular}

Centaurea nigra-also on chalk.

Poa trivialis-perhaps characteristic of the heavier soils.

Equisetum arvense

Lychnis Githago

Potentilla Anserina

Prunella vulgaris $\left\{\begin{array}{l}\text { more usual on loams, but also } \\ \text { associated with other types } \\ \text { of soil. }\end{array}\right.$

\section{Sand and Sandy Loams.}

These soils are met with all over the county, and in most cases represent the sand and gravel deposits, in others the lightest types of Boulder Clay. In some places the sands are deficient in calcium carbonate; in others, where the chalk rock comes near the surface, they are decidedly calcareous, containing chalk stones, as is well seen at Hargham and East Snettisham. In the north-west of the county the Lower Greensand crops out in the form of 'carstone', which yields a peculiar type of sandy soil deficient in chalk, 
giving no effervescence when treated with dilute hydrochloric acid. These carstone soils are well seen at Dersingham, West Snettisham, and Heacham, and are usually of a decided red or yellow colour. The relative quantities of calcium carbonate in the sands are reflected in the flora, such so-called 'acid' or 'sour' plants as Rumex Acetosella and Spergula arvensis never being found on the calcareous sands. It is hardly correct to say that such plants as Rumex Acetosella are definitely symptomatic of 'acid' soils. An acid soil is what is known to the agriculturist as a sour soil, the use of the technical word acid in this connexion being rather unfortunate. A sour soil implies one containing no chalk at all, so that an acid reaction is obtained with litmus paper. Rumex Acetosella will grow on soils which do contain a very small percentage of calcium carbonate, as can be seen at Blakeney Point, so that it is better to say that the so-called acid plants are really indicators of soils deficient in chalk, though total absence of calcium carbonate is not necessarily entailed. Warming ${ }^{1}$ suggests that nearly all lime soils are rich in soluble mineral substances and that this wealth excludes plants belonging to poorer soils, owing to the competition of plants which flourish best on the richer soils. Cultures made by C. A. Weber and Grubner have clearly demonstrated that none of the calciphobous plants, of which Rumex Acetosella is an example, suffer from lime when this is unaccompanied by a large amount of soluble salts, and that they are expelled from calcareous soils by competition. Nevertheless, from a practical agricultural point of view, the presence of calciphobous plants on any land is undoubtedly a sure indication of a deficiency of the chalk which is so essential to the well-being of most plants.

In the present investigation sour soils other than sands have not often come into notice, so that it is not yet possible to say whether there is a flora that is characteristic of sour land of heavier texture.

The lighter soils are characterized by the great diversity of plants composing their flora, a good proportion of the species being definitely characteristic of sand and sandy loams. The classification is as follows :

Chrysanthemum segetum Rumex Acetosella Scleranthus annuus Spergula arvensis

symptomatic of light sandy soils which are very deficient in chalk.
Bromus mollis
Echium vulgare
Erophila verna
Lycopsis arvensis
Myosotis collina 
Erodium cicutarium

Gnaphalium uliginosum

Holcus lanatus

Linaria minor

Rumex obtusifolius

Sagina nodosa

Silene gallica

Urtica dioica

Alchemilla arvensis

Juncus bufonius

Lamium amplexicaule

Polygonum Persicaria

Scabiosa arvensis

Sisymbrium Thalianum

Veronica agrestis

Veronica hederaefolia

Matricaria Chamomilla-also on heavy loam.

Arenaria serpyllifolia

Anthemis arvensis

Carduus nutans

Centaurea Scabiosa

Filago germanica

Geranium molle

pusillum
Raphanus Raphanistrum

Reseda lutea

Satureia Acinos

Silene noctiflora characteristic of sand and sandy loam.

also on loam.

Papaver Rhoeas-also on chalk and light loam.

\section{Chalk and Calcareous Soils.}

Chalk is found underlying the drift soils over the greater part of Norfolk, but in the eastern and central parts of the county it is usually so deeply situated that it does not affect the surface soils. In West Norfolk, however, an outcrop occurs, so that in some places real chalky land is found, derived directly from the chalk rock, while in others the drift overlying the chalk is decidedly calcareous in nature, due to admixture with the chalky subsoil. Comparatively little of this chalk soil was met with in the season's work, so that it was not possible to definitely associate many species with such land. 
Brenchley. - The Weeds of Arable Land. III. I I I

Artemisia vulgaris

Cichorium Intybus

Crepis virens

Euphorbia Helioscopia

Linaria vulgaris

Aethusa Cynapium

Centaurea nigra also on loam.

Anthemis arvensis

Arenaria serpyllifolia

Atriplex patula

Carduus nutans

Centaurea Scabiosa

Filago germanica

Geranium molle

probably characteristic.

" pusillum

Raphanus Raphanistrum

Reseda lutea

Satureia Acinos

Silene noctiflora

also on sandy soils.

Papaver Rhoeas-also on sand and loam.

\section{Weeds of General Occurrence.}

Besides the species which are definitely associated with particular soils, there are a good many plants which occur indiscriminately on any and every kind of land, while others, though absent from one type of soil, are otherwise universally distributed. Into this category come the following:

Agrostis stolonifera

Brassica Sinapsis

Capsella Bursa-pastoris

Caucalis nodosa

Cerastium vulgatum

Chenopodium album

Cirsium arvense

Convolvulus arvensis

Daucus Carota

universally distributed.

Galium sp.

Lamium purpureum

Lychnis alba

Matricaria inodora

Mentha arvensis

Plantago lanceolata

" major

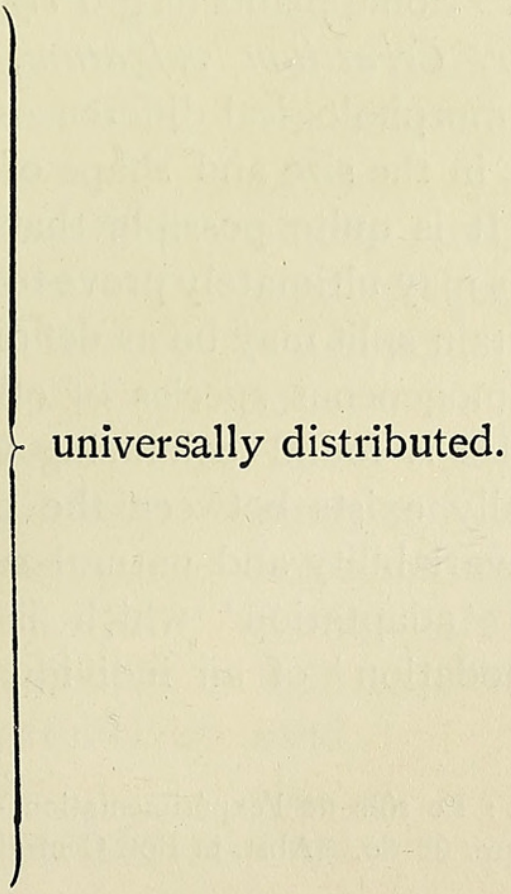




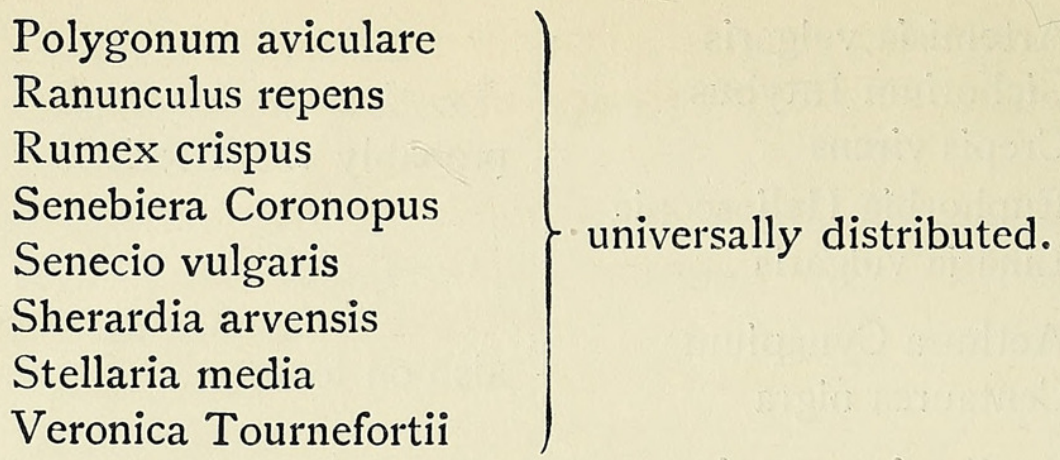

Sonchus arvensis-especially on clay.

Chaerophyllum Anthriscus

Fumaria officinalis

Glechoma hederacea

Silene inflata

Veronica arvensis

Viola tricolor

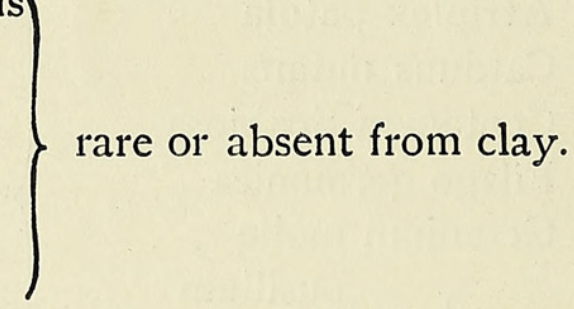

Anagallis arvensis

Myosotis arvensis

Poa annua

scarce on chalk.

Bartsia Odontites

Erysimum cheiranthoides

Polygonum Convolvulus

Scandix Pecten-veneris

Taraxacum vulgare

Triticum repens

absent from chalk.

Some of the above species are both universally distributed and abundant in occurrence. Some plants (e.g. Polygonum aviculare, Chenopodium album, Viola tricolor, Cerastium vulgatum, Capsella Bursa-pastoris, \&c.) show considerable morphological differences in different places, exhibiting variations in habit, in the size and shape of the leaves, in the size and colour of the flowers. It is quite possible that 'splits' or varieties of these cosmopolitan species may ultimately prove to be as significant as species themselves, and that a certain split may be as definitely associated with a particular type of soil as homogeneous species of other genera. Massart ${ }^{1}$ suggests that when a species is found colonizing very diverse habitats, some essential difference really exists between the plants, and that under the combined influences of variability and natural selection a species undergoes a transformation or 'adaptation' which is hereditary, in contradistinction to the 'accommodation' of an individual to place itself in accord with its habitat.

1 Massart, I.: Le rôle de l'expérimentation en géographie botanique. Rec. Inst. bot. Léo Errera, ix, I9I 2, pp. 68-80. Abst. in Bot. Centralbl., Band cxx, No. I4, pp. 353-4. 
Besides the weeds mentioned in the foregoing lists the following were seen very occasionally, some only appearing once in the season's work :

\begin{tabular}{|c|c|c|}
\hline Ranunculaceae & Myosurus minimus & sand \\
\hline " & Ranunculus acris & loam \\
\hline$"$ & bulbosus & sand and heavy loam \\
\hline Papaveraceae & $\begin{array}{l}\text { Papaver dubium } \\
\quad \text { hybridum }\end{array}$ & $\begin{array}{l}\text { heavy loam } \\
\text { chalk }\end{array}$ \\
\hline Cruciferae & Lepidium campestre & loam \\
\hline$"$ & Sisymbrium Sophia & sand \\
\hline & Thlaspi arvense & \\
\hline Resedaceae & Reseda luteola & light loam \\
\hline Caryophyllaceae & Sagina procumbens & sandy loam \\
\hline Malvaceae & Malva sylvestris & chalky soils \\
\hline Geraniaceae & Geranium pyrenaicum & light loam \\
\hline Leguminosae & Anthyllis Vulneraria & sand and chalk \\
\hline$”$ & $\begin{array}{l}\text { Melilotus alba } \\
\text { arvensis }\end{array}$ & sandy loam \\
\hline ”, & Ornithopus perpusillus & sana \\
\hline Rosaceae & Potentilla sterilis & sandy loam \\
\hline Saxifragaceae & Saxifraga tridactylites & sand \\
\hline Umbelliferae & Anthriscus sylvestris & loam \\
\hline & Pimpinella Saxifraga & chalk \\
\hline Valerianaceae & Valerianella olitoria & sandy loam \\
\hline Compositae & Cirsium lanceolatum & \\
\hline Compositae & Cirsium lanceolatum & distributed \\
\hline , & Erigeron canadensis & sandy soils \\
\hline ” & Filago minima & sand \\
\hline$"$ & Hypochaeris radicata & heavy loam \\
\hline ” & Lapsana communis & distributed \\
\hline ” & Picris Hieracioides & loam \\
\hline , & Onopordon Acanthium & chalky sand \\
\hline & Senecio Jacobaea & sand and gravel \\
\hline Boraginaceae & Lithospermum arvense & distributed \\
\hline Scrophulariaceae & Linaria spuria & loam \\
\hline " & Verbascum Thapsus & $"$ \\
\hline , & Veronica serpyllifolia & sandy soil \\
\hline Orobanchaceae & Orobanche minor & loam and sand \\
\hline Lamiaceae & Stachys arvensis & chalky loam \\
\hline Chenopodiaceae & Chenopodium urbicum & light soil \\
\hline Polygonaceae & Polygonum lapathifolium & sand \\
\hline Euphorbiaceae & $\begin{array}{l}\text { Rumex Acetosa } \\
\text { Euphorbia platyphyllos }\end{array}$ & loam \\
\hline
\end{tabular}


Urticaceae

Graminaceae

$"$
$"$
Polypodiaceae
Urtica urens

Aira caryophyllaea

Alopecurus pratensis

Bromus sterilis

Poa pratensis

Pteris aquilina sand

light loam
heavy loam
loam
sand

\section{COMPARISON OF THE WEED Flora OF NORFOLK WITH THAT OF BEDFORDSHIRE AND THE WEST COUNTRY.}

The general aspects of the weed floras are more or less comparable as regards the distribution of the plants, but the number of the species occurring is considerably greater in Norfolk, partly because of the greater diversity in the soil and partly on account of the larger area covered by the investigation. Some few of the weeds are proving to have a real association with definite types of soil, while yet others show decided local differences in their distribution, being absent in one place from the very soil on which they are frequent or even characteristic in another locality. The question as to calcifuges can hardly be reopened at present, as so little chalk land was examined in Norfolk that the data is too meagre. Just one plant, Poa annua, stands out conspicuously in that it is the only plant that has proved to be consistently absent or very rare on chalk in each of the three districts.

On the whole there is a closer correspondence between the weed floras of Norfolk and Bedfordshire than between that of the West Country and the Eastern Counties, both as regards distribution and the actual species found, a fact which may be due to the geographical proximity and to a closer approximation in the nature of the soils in the east.

The most outstanding features of distinction and similarity are :

I. Certain species are definitely associated with sand, always choosing that as a habitat in every locality:

$\begin{array}{ll}\text { Chrysanthemum segetum } & \text { Sisymbrium Thalianum } \\ \text { Rumex Acetosella } & \text { Spergula arvensis } \\ \text { Scleranthus annuus } & \end{array}$

Brassica arvensis, on the other hand, shows a consistent dislike of sandy soils. This is borne out by the work of Verhulst, ${ }^{1}$ who states that his researches show that no affinity exists between Sinapsis arvensis (Brassica arvensis) and light soils. He finds Brassica arvensis to be characteristic of chalky soils and calcareous clays, while Raphanus Raphanistrum is confined to sand, clays, and non-calcareous muds, though where the nature of the soil

1 Verhulst, A.: Quel est le vrai charactère biologique du Raphanus Raphanistrum, L., et du Sinapsis arvensis, L.? Bull. Soc. Roy. Bot. Belgique, 48. 4. 1911, pp. 248-56. Abst. in Bot. Centralb. Band cxx, No. 12, p. 317 . 
is variable the two species occur pell-mell in various proportions. $\mathrm{He}$ also concludes that Raphanus is calcifuge and Brassica arvensis calcicolous, but this statement is not borne out in its entirety by the present investigations, though broadly it meets the case.

2. While Poa annua and Anagallis arvensis have a dislike for chalk, other plants are always to be found on calcareous land, though they are frequently seen on light soils as well. The chief of these are :

$\begin{array}{ll}\text { Centaurea Scabiosa } & \text { Silene inflata } \\ \text { Papaver Rhoeas } & \text { Viola tricolor } \\ \text { Reseda lutea } & \end{array}$

3. Euphorbia exigua and Ranunculus arvensis have always proved to be characteristic of heavy land, i. e. heavy loam and clay.

4. The following species show very striking distinctions in their distribution in different districts :

Bartsia Odontites. Never recorded from chalk in Norfolk or Bedfordshire and usually seen on the heavier soils. Characteristic of chalk in the West Country and seldom seen on the heavy land.

Chenopodium album. Bedfordshire. Never recorded from chalk, most frequent on sand and light loam.

West Country. Frequently seen on chalk and clay, but absent from sand.

Norfolk. Usually distributed over all types of soil.

Myosotis arvensis. Bedfordshire. Found on all soils.

West Country. Characteristic of chalk land.

Norfolk. Rare on chalk.

Ramunculus repens. Rare on chalk in the east, but frequent on calcareous land in the West Country.

Scandix Pecten-veneris. Bedfordshire. Practically distributed.

West Country. Characteristic of and practically confined to chalk.

Norfolk. Absent from chalk, and characteristic of clay and loam.

\section{Relations existing Between the Weeds and the Crops.}

After three seasons' work in the fields it is gradually becoming possible to interpret the earlier results in the light of the current year's work. The first impression obtained was that the crop played very little part in determining the weed flora, while the nature of the soil practically settled everything. Leguminous plants proved to be an exception to this rule, presumably because they tend to smother out certain weeds owing to their peculiarly leafy habit of growth, and also because certain other weeds seem to be habitually introduced with the seeds. 
In a recent study on the purity of agricultural seeds Borlase ${ }^{1}$ gives the following weed seeds as commonly occurring as impurities in samples of clover and other leguminous seeds :

Bromus mollis

Caucalis Anthriscus

Festuca bromoides

Geranium dissectum

, molle

Lychnis alba
Plantago lanceolata

Poa annua

Prunella vulgaris

Rumex Acetosella

" crispus

Sherardia arvensis

Chrysanthemum leucanthemum, Rumex Acetosa, and Lychnis diurna are also occasionally found. It appears that Geranium dissectum is the species of Geranium commonly associated with Red Clover seeds, while Geranium molle is found among Alsike and White Clover seeds. With regard to cereals and roots Borlase states that 'in the former there are very few weed seeds, as their presence would be easily detected owing to differences in size and colour, and with the latter difference of shape and colour would reveal most to the naked eye'. He also quotes two samples of weeds introduced with imported seeds which have established themselves as serious pests in parts of Cornwall. Bromus secalinus is a bad best in the Winter Oat crop, but in no other, and may have been introduced from Canada, where it is common and is known as 'Cheat'. Matricaria suaveolens was introduced into Cornwall about fifteen years ago from North Asia or Western North America, and is now so prevalent in some places that it absolutely destroys the corn crops.

It is now evident that while the soil is the primary determining factor, still the nature of the crop plays a larger part than was originally supposed. While this influence is partly due to the different habits of the crops, it is probably more the result of the varying methods of cultivation applied to the crops. Broadly speaking, a four-course rotation is usually followed in the district studied :
(I) Wheat.
(2) Roots.
(3) Barley or oats.
(4) Seeds and leguminous crops.

With the seed crops nothing can be done to keep the land clean, so the weed flora among the ensuing wheat tends to be specially fruitful in the varieties occurring in the young corn, though if the crop is very heavy it tends to strangle many of the weeds later on, a fact that is usually attributed to the exclusion of light and air. With the root crops comes the

1 Borlase, W. : The Study of Agricultural Seeds. Journ. Board. Agric., xix, No. 7, pp. 529-4I. $\mathrm{I}$ am also indebted to $\mathrm{Mr}$. Borlase for a private communication in which he gave me much of the information in this paragraph. 
opportunity for a thorough cleaning of the land with cultivator and hoe, so many species which cannot withstand such drastic treatment tend to be conspicuous by their absence among roots. The barley and oats make a fair start on clean ground, and if the seed crop of clover, \&c., is put down with the grain and makes fair growth, the weeds are very few in number and variety, as they have no chance to get a fair start in life before they are smothered out of existence. The seed crops offer quite different conditions. No cultivation is possible among such crops as clover and lucerne, so any weed seeds in the soil or introduced with the 'seeds' have the opportunity to germinate and flourish undisturbed if only they can compete successfully with the overshadowing of the crop ; but many species fail utterly in doing this, and so are generally absent from seed crops, while others seem to make a speciality of growing under such conditions.

For working purposes it has proved necessary to divide up the seed crops into two classes, as the weed floras are frequently distinctive:

'Seeds'-clover, temporary pasture, grasses.

'Legumes'-peas, beans, lucerne, sainfoin, lupins.

In the I9I 2 season some plants were found to be absent from seed and from root crops, while a few others were nearly always associated with cereals alone or with cereals and roots.

Weeds absent or very rave in seed crops.

Agropyron repens

Agrostis stolonifera

Alopecurus myosuroides

Chenopodium album

Erysimum cheiranthoides

Galium Aparine

Gnaphalium uliginosum

Legousia hybrida

Poa annua

Polygonum aviculare
Polygonum Convolvulus Persicaria

Rumex obtusifolius

Scandix Pecten-veneris

Silene inflata

Spergula arvensis

Stellaria media

Taraxacum vulgare

Veronica hederaefolia

\section{Weeds absent or very rare in root crops.}

Aethusa Cynapium

Alchemilla arvensis

Alopecurus myosuroides

Anthemis arvensis

Bartsia Odontites

Bellis perennis

Cerastium vulgatum

Cichorium Intybus

Crepis virens
Daucus Carota

Echium vulgare

Erophila verna

Euphorbia exigua

Holcus lanatus

Lychnis Githago

Lycopsis arvensis

Matricaria Chamomilla

" inodora 
Nepeta hederacea

Reseda lutea

Rumex obtusifolius
Taraxacum vulgare

Veronica arvensis

Weeds only associated with cereal crops.

Anthemis Cotula

Galeopsis Tetrahit

Heracleum Sphondylium

Juncus bufonius

Lapsana communis
Lolium perenne

Poa trivialis

Ranunculus arvensis

Sagina nodosa

Sisymbrium officinale

\section{Weeds only associated with cereals and roots.}

Brassica arvensis

Centaurea nigra

Chrysanthemum segetum

Fumaria officinalis

Lamium amplexicaule
Lamium purpureum

Linaria minor

Raphanus Raphanistrum

Senebiera Coronopus

Silene noctiflora

Weeds only associated with seeds and legumes.

Cirsium lanceolatus

Geranium dissectum

Filago germanica

Comparison with the Bedfordshire results (I910) show that many species are consistently absent from or very rare in seed crops in both districts.

Nearly all the weeds are to be found to some extent among the cereal crops, and generally the kind of cereal makes no difference. A few plants, however, seem to exercise some selection as to which cereal crop in the rotation they associate with. Most of these species are generally or exclusively found with wheat, while yet a few more are never seen with the corn, but only with barley or oats.

\begin{tabular}{|c|c|}
\hline $\begin{array}{l}\text { Anthemis Cotula } \\
\text { Erophila verna } \\
\text { Juncus bufonius } \\
\text { Poa trivialis } \\
\text { Sagina nodosa }\end{array}$ & always found with wheat. \\
\hline $\begin{array}{l}\text { Alchemilla arvensis } \\
\text { Alopecurus myosuroides } \\
\text { Cerastium vulgatum } \\
\text { Chrysanthemum segetum } \\
\text { Heracleum Sphondylium } \\
\text { Ranunculus arvensis } \\
\text { Rumex obtusifolius } \\
\text { Triticum repens }\end{array}$ & usually found with wheat. \\
\hline
\end{tabular}


Artemisia vulgaris

Carduus nutans

Linaria minor

Raphanus Raphanistrum

never with wheat; always with

barley or oats.

Silene gallica

In all probability this selectivity is the result of some peculiar adaptation to the particular cultural conditions of the associated crop. This association with particular cereal crops is, however, not yet proved universally. So far as the species correspond, there is a fairly close agreement between the Bedfordshire and Norfolk results, but in the West Country some species, as Alopecurus myosuroides, Heracleum Sphondylium, Chrysanthemum segetum, are associated with wheat, barley, and oats instead of being chiefly found with wheat as they are in the Eastern Counties. This may prove to be due to differing local customs with regard to the growing of Spring or Winter Oats, but information on this point is not immediately available.

When the tabulated results for the three years are placed side by side and compared, it is seen that certain of the weeds are always to be found in association with all types of crop in the different districts. Other species are apparently more variable-perhaps they are rather more sensitive to differences of local conditions - and so while they may be associated with every type of crop in one place, they may be absent from one or other of the crops in another district. A few plants are much more rigid in their adherence or aversion to some particular crop. For instance, the following plants have been frequently observed in each of the three seasons, and consistently they have been found to be either absent or very rare among root crops :

\section{Anthemis Cotula \\ Bartsia Odontites \\ Cerastium vulgatum \\ Plantago lanceolata}

Ranunculus acris

Taraxacum vulgare

This probably indicates that these plants are particularly impatient of interference, and so they find a position among the root crops untenable on account of the repeated cultivation carried on.

Again, some other species seem to be quite unable to cope with the keen competition for light, and possibly for air, that occurs among the seed crops, as is indicated by the rarity with which the following are found in such surroundings :

Agropyron repens

Gnaphalium uliginosum

Legousia hybrida
Poa annua

Veronica hederaefolia 
This hypothesis is upheld by the behaviour of two species of Polygonum, $P$. aviculare and $P$. Convolvulus. These plants were exceedingly rare among seeds in Norfolk and Bedfordshire during two seasons in which plenty of rain had fallen, so that the crop had made good growth, rendering competition keen. In the West Country both these Polygonums were found with seeds, but this was in a very dry season in which a long period of drought immediately succeeded the sowing of the crop. As a result little growth was made, thus enabling these sensitive weeds to get their footing in an unusual habitat.

A very few plants seem to be even more exclusive in their association, the following species being found only with cereals :

\section{Lapsana communis Plantago media \\ Lolium perenne Poa trivialis}

The indications are that many of the weeds will ultimately prove to have a very decided preference for or abhorrence of some particular class of crop, but that these individual peculiarities are liable to be modified by local conditions, although some plants may prove strong enough to master the local variations, so remaining consistent in their crop association.

The question arises as to the effect of impurities in the seeds sown upon the weed flora. Broadly speaking, the effect is not well marked. Of all the impurities indicated by Borlase ${ }^{1}$ as occurring in Leguminous seeds, Geranium dissectum is the only one which is confined to such crops during growth. Poa annua, which is introduced with the crop seed, is conspicuous by its absence in the grown crop. At present it does not seem possible to draw any conclusion with regard to this point. In the cereals so few weed seeds are sown that their effect is practically negligible.

\section{Points of Special Interest.}

I. The different orders of flowering plants vary very much in the contribution they make to the weed flora of the arable lands. Many of them provide just one or two species, but when the large orders are considered the differences in representation are very striking. Leguminosae, Rosaceae, Umbelliferae, and Chenopodiaceae are very poorly represented, both relatively in proportion to the size of the orders, and actually in the number of species occurring as weeds, Lamiaceae being very little better. Ranunculaceae, Papaveraceae, Geraniaceae, and Euphorbiaceae each provide one main genus, but in each case several members of that genus are commonly found. 
Scrophulariaceae is very much to the fore with the genera Veronica and Linaria, both of which yield several species, the Veronicas being among the most common of weeds. Cruciferae and Caryophyllaceae are each represented by several genera with about one species from each as a rule, though the genera Brassica (Cruciferae) and Lychnis and Silene (Caryophyllaceae) are very rich in their contribution of species. Polygonaceae, again, is particularly well marked with several species of Polygonum and Rumex, which have the doubtful distinction of being among the commonest and worst weeds from the farmer's point of view. Graminaceae yields a fair number of species from different genera, but the weed order is undoubtedly Compositae so far as the number of representatives is concerned, for at least half the British genera of this large order contribute one or more of their species to the weed flora. The distribution of the Compositae, too, is very wide, both as regards the soils and crops with which they are associated.

The analyses indicate that the cultivated fields provide a definite ecological habitat, which is differently adapted to the support of the various great families of plants.

2. Different species of the same genus are often distinctive in the type of soil they characteristically inhabit, as the following well-marked instances show :

Anthemis arvensis

Cotula

Carduus nutans $" \quad$ arvensis

Chrysanthemum Leucanthemum " segetum

Euphorbia exigua

$\begin{array}{ll}״ & \text { Helioscopia } \\ , \quad & \text { Peplus }\end{array}$

Geranium dissectum

$$
\begin{array}{ll}
" \quad \text { molle } \\
, \quad \text { pusillum }
\end{array}
$$

Linaria Elatine

" minor

$$
\text { " vulgaris }
$$

Polygonum aviculare

$\begin{array}{ll}" & \text { Convolvulus } \\ , & \text { Lapathifolium } \\ , & \text { Persicaria }\end{array}$

Ranunculus acris

$$
\begin{array}{ll} 
& \text { arvensis } \\
& \text { repens }
\end{array}
$$

sandy soils and chalk

loam

calcareous soils

distributed

loam

sand

heavy loam and clay

calcareous soils

loam

heavy loam and clay

light and chalky soil

heavy soils

sandy soils

calcareous soils

distributed

loam and sand

sand

light sandy soils

loam

heavy loam and clay

distributed 
Rumex Acetosella

" crispus

„ obtusifolius 'acid' sandy soil

distributed

sandy soil

These records agree in most respects with those obtained in the West Country in I9II, except in that certain plants seem rather more varied in their distribution in Norfolk.

In contradistinction to the above, the genus Veronica with all its different species is typically characteristic of the sandy and light soils, $V$. Tournefortii being the only one that is found to any extent on heavy land.

3. In one district, round Swaffham and Narborough, certain fields were observed to carry a flora composed of the most curious mixture of plants. Species usually associated with chalky land were found growing side by side with others characteristic of sandy soils, and even of 'acid' soils. In one case a field that used to be cultivated had been left for several years untouched, and in it were found, among other plants, Poterium Sanguisorba, Anthyllis Vulneraria, and Reseda lutea, all calcicolous plants, together with Rumex Acetosella, a decided calcifuge.

In another instance, Reseda lutea, Linaria vulgaris, Centaurea Scabiosa, with other less distinctive chalk plants, were found plentifully in a very sandy field in which Scleranthus anmuns occurred and in which Spergula arvensis was dominant.

These sandy soils were evidently very shallow, overlying a chalk subsoil, and the possible explanation presents itself that the differences in the root systems of the plants may account for the apparent anomaly. From a cursory examination it appears as if most of the acid species found are relatively shallow rooted, and so are able to flourish in the sandy surface layers of soil, while the chalk plants are provided with larger roots and so find it possible to strike right through the unfavourable strata and to draw on the underlying stores of chalk for their nutriment. This supposition with regard to the relative lengths of the roots needs far more confirmation before it can be accepted as proved.

4. At least four varieties of the Mayweeds occurred in the Norfolk fields. Of these, Matricaria inodora was the only species that was found distributed on all kinds of soils, heavy as well as light, the others being practically confined to the lighter lands. Anthemis Cotula was generally a denizen of loams, Anthemis arvensis of sandy soils and chalk, while Matricaria Chamomilla reserved itself for either sand or heavy loam. Once again the Mayweeds proved to be very impatient of competition, as not only were they rarely to be found in among the crops, but only at the edges and in open spaces, but also they were universally absent from root crops, where the additional factor of cultivation has to be competed with.

5. A very striking feature of the sandy soils in Norfolk is the presence 


\section{Brenchley.-The Weeds of Arable Land. III. ${ }_{163}$}

of Lycopsis arvensis and Echium vulgare, both showy plants with conspicuous blue flowers. It is impossible to give a definite opinion on the one season's records, but it seems probable that both are usually characteristic of calcareous sands as opposed to acid soils.

\section{Common and Local Names.}

For the purposes of reference an alphabetical list of the more important weeds is appended, giving the common and, where possible, the local names :

Achillea Millefolium

Aethusa Cynapium

Agropyron repens

Agrostis stolonifera

Alchemilla arvensis

Alopecurus myosuroides

Anagallis arvensis

Anthemis arvensis

Cotula

Anthriscus Scandix

Arenaria serpyllifolia

Artemisia vulgaris

Atriplex patula

Bartsia Odontites

Bellis perennis

Brassica alba

arvensis

Capsella Bursa-pastoris

Carduus nutans

Caucalis nodosa

Centaurea nigra

Scabiosa

Cerastium vulgatum

Chenopodium album

Chrysanthemum segetum

Cichorium Intybus

Cirsium arvensis

Convolvulus arvensis

Daucus Carota

Echium vulgare

Equisetum arvense

Erodium cicutarium

Erysimum cheiranthoides

Euphorbia exigua
Yarrow

Fool's Parsley

Couch, Twitch

Twitch, Couch, Bent-grass

Lady's Mantle

Field Foxtail, Black Bent

Scarlet Pimpernel, Poor Man's Weather Glass

Corn Chamomile, Mayweed

Stinking Chamomile, Mayweed

Beaked Parsley

Thyme-leaved Sandwort

Mugwort, French Tobacco

Common Orache

Red Bartsia

Daisy

Charlock, White Mustard

Charlock

Shepherd's Purse

Musk Thistle, Dog Thistle

Knotted Hedge-parsley

Hardhead, Bunk, Knapweed

Greater Knapweed, Bunk.

Mouse-ear Chickweed

Fat Hen, Mutton Tops, Lamb's Quarters

Corn Marigold, Yellow Daisy .

Chicory

Creeping Thistle

Bindweed, Wild Convolvulus

Carrot

Viper's Bugloss

Horsetail, Mare's-tail, Cat's-tail

Common Stork's-bill

Treacle Mustard

Dwarf Spurge 
Euphorbia Helioscopia

" Peplus

Filago germanica

Fumaria officinalis

Galeopsis Tetrahit

Galium Aparine

Geranium dissectum

$$
\begin{array}{ll}
" \quad \text { molle } \\
\text { pusillum }
\end{array}
$$

Gnaphalium uliginosum

Heracleum Sphondylium

Holcus lanatus

Juncus bufonius

Lamium amplexicaule

$$
" \text { purpureum }
$$

Lapsana communis

Legousia hybrida

Linaria Elatine

$$
\begin{array}{ll}
\text { " minor } \\
\text { vulgaris }
\end{array}
$$

Lolium perenne

Lychnis alba

$$
\text { " Githago }
$$

Lycopsis arvensis

Malva sylvestris

Matricaria Chamomilla inodora

Mentha arvensis

Myosotis scorpioides

Nepeta hederacea

Papaver Argemone

" Rhoeas

Plantago lanceolata

Poa annua major

"trivialis

Polygonum aviculare

" Convolvulus
Persicaria

Potentilla Anserina

Ranunculus acris
Sun Spurge

Petty Spurge, Wee Gweedie

Upright Cudweed

Fumitory

Hemp-nettle

Cleavers, Goosegrass, Robin-run-the-hedge, Clider

Cut-leaved Crane's-bill

Dove's-foot " ,

Small

Marsh Cudweed

Hogweed, Haletrot, Rabbit-food

Yorkshire Fog

Toadrush

Hen-bit

Red Dead-nettle

Nipplewort

Corn Campanula, Venus's Looking-glass

Pointed Fluellen

Small Toadflax

Yellow Toadflax

Rye-grass

White Campion, Cockle

Corn Cockle

Field Alkanet

Mallow, Pig-cheese

Wild Chamomile, Mayweed

Scentless Mayweed

Field Mint

Field Scorpion-grass, Forget-me-not

Ground Ivy

Rough-headed Poppy, Pale Poppy

Red Poppy, Redweed

Ribwort Plantain, Rib-grass

Great

Annual Meadow-grass

Rough

Crab-grass, Stoneweed, Pigweed, Iron-grass, Ironweed, Wire-grass, Wireweed, Knotgrass

Black Bindweed

Spotted Persicaria

Silverweed

Buttercup, Ram's-glass 
Ranunculus arvensis Corn Crowfoot, Bur Buttercup

" repens Creeping Buttercup

Raphanus Raphanistrum Radish, Charlock, Charlick

Reseda lutea

Wild Mignonette

Rumex Acetosella

Sheep Sorrel

" crispus

Common or Curled Dock

" obtusifolius

Broad-leaved Dock

Satureia Acinos

Scabiosa arvensis

Calamint

Scandix Pecten-veneris

Scleranthus annuus

Field Scabious, Corn Flower

Senebiera Coronopus

Senecio Jacobaea

" vulgaris

Sherardia arvensis

Silene anglica

$$
" \quad \text { inflata }
$$

Shepherd's Needle, Venus's Comb

Knawel

Swine-cress

Ragwort, Cankerweed

Groundsel

Field Madder

English Catchfly

Bladder Campion

Sisymbrium Thalianum

Sonchus arvensis

Spergula arvensis

Stellaria media

Taraxacum vulgare

Tussilago Farfara

Urtica dioica

Night-flowering Catchfly

Veronica agrestis $"$ arvensis

" hederaefolia

"Tournefortii

Viola tricolor

Sow Thistle, Milk Thistle

Spurrey, Sand-grass, Makebeg

Chickweed

Dandelion

Coltsfoot, Floatweed

Stinging Nettle

Field Speedwell

Wall

Ivy-leaved Speedwell

Buxbaum's Speedwell, Cuckoo's Leader

Wild Pansy, Kiss-me-over-the-garden-gate, Lovein-idleness.

\section{SUMMARY。}

I. The close association existing between the weeds of arable land and the soils on which they grow holds good for 'drift' soils as well as for those derived from the underlying rocks. As before, the texture of the soil was more important than its derivation in determining the weed flora.

2. It was again found that this association may be either-

(a) General. When a weed is always associated with one type of soil in every district.

(b) Local. When a weed associated with a soil in one district is absent from or rare on similar land in other places. 
3. On the whole the Norfolk and Bedfordshire weed floras compare more closely with one another than with that of the West Country, a fact attributed partly to geographical proximity and partly to closer approximation in the nature of the soil in the Eastern Counties.

4. A closer relationship evidently exists between the weeds and the crop than has hitherto been recognized. This is probably largely due to the particular conditions of cultivation of the various crops and to their place in the rotations practised.

5. It is possible that a very few species will prove to have a preference for growing with wheat, while yet a few others are very rare with that crop. This suggestion, however, is very tentative as yet.

6. The different orders of flowering plants contribute to the weed flora in varying proportions, some of the larger orders being represented by very few species, while others are most generous in the contribution they make.

7. When several members of a genus occur as weeds, it frequently happens that each is a denizen of one particular type of soil characteristic to itself.

8. In one district a curious mingling of ' acid' and 'chalk' plants was found, possibly owing to the superposition of a thin layer of a non-calcareous sand on a chalk subsoil, the difference in the root systems of the plants enabling each to tap the particular soil most suited to its needs.

In conclusion, I wish to express my indebtedness to Professor T. B. Wood and to Sir Eustace Gurney for the many introductions which alone made the work possible in Norfolk, and also to Mr. W. A. Nicholson, who identified many of the doubtful specimens which came to hand. It is not possible to acknowledge by name all those who have aided me by hospitality and advice during the progress of the research, but to all such I desire to tender my grateful thanks. 


\section{$2 \mathrm{BHL}$ Biodiversity Heritage Library}

Brenchley, Winifred E. 1913. "The weeds of arable land. III." Annals of botany 27, 141-166. https://doi.org/10.1093/oxfordjournals.aob.a089447.

View This Item Online: https://www.biodiversitylibrary.org/item/237410

DOI: https://doi.org/10.1093/oxfordjournals.aob.a089447

Permalink: https://www.biodiversitylibrary.org/partpdf/319963

\section{Holding Institution}

Smithsonian Libraries

\section{Sponsored by}

Biodiversity Heritage Library

\section{Copyright \& Reuse}

Copyright Status: Not in copyright. The BHL knows of no copyright restrictions on this item.

This document was created from content at the Biodiversity Heritage Library, the world's largest open access digital library for biodiversity literature and archives. Visit BHL at https://www.biodiversitylibrary.org. 